\title{
ANALISIS PEMAKAIAN BENT UK-BENT UK PRONOMINA PERSONA DALAM NOVEL TAHAJUD CINTA DI KOTA NEW YORK KARYA ARUMI E.
}

\author{
Rafhiqi Pratama, Sujoko
}

The purpose of this research is to decribe the use of first personal pronoun, second personal pronoun, third personal pronoun in the novel Tahajud Cinta di Kota New York by Arumi E. This research is descriptive qualitative research. The primary data is a written text in form of quotations that contain personal pronoun in the novel Tahajud Cinta di Kota New York by Arumi E. The data is collected by using libarary study and documentation technique which focuses on analyzing the types of personal pronoun in the novel Tahajud Cinta di Kota New York by Arumi E. The data is analyzed by using analysis and decriptive technique.

Based on the result of the research it can be concluded that the types of personal pronoun are represented in the novel Tahajud Cinta di Kota New York by Arumi E. There are 559 data which is divided into three types of personal pronoun.

Key Words: analysis, personal pronoun, novel

\section{PENDAHULUAN}

Secara garis besar, bahasa sebagai alat komunikasi bagi masyarakat. Melalui bahasa, masyarakat dapat saling berkomunikasi, berinteraksi, bekerja sama, dan mengidentifikasi diri. Dengan bahasa yang baik masyarakat sekaligus penulis karya sastra dapat menyampaikan ide, gagasan, pendapat, pengalaman, serta pesan kepada orang lain melalui karya sastra yang diciptakannya. Dengan bahasa yang baik pula masyarakat maupun penulis dapat mengkomunikasikan perihal dalam kehidupan maupun di dalam karya sastranya. Pengguna bahasa yang baik akan menentukan pribadi seseorang.

Bahasa memegang peranan penting dalam kehidupan sehari-hari. Bahasa memliki dua ragam, yakni ada ragam bahasa lisan dan ada ragam bahasa tulisan. Ragam bahasa lisan merupakan ragam bahasa yang penekanannya pada intonasi atau lagu kalimat ketika kita menggunakannya. Wujud dari ragam bahasa lisan akan terlihat dari cara bicara seseorang. Cara bicara seseorang akan sangat menentukan situasi dan kondisi dalam berkomunikasi, ragam bahasa lisan dengan penekanan yang tepat akan memudahkan orang memahami apa yang disampaikan secara lisan. Sebaliknya cara bicara yang tidak santun dan tidak memperhatikan penekanan intonasi atau lagu kalimat dapat membiaskan makna bagi pendengar. Sedangkan ragam bahasa tulisan merupakan ragam bahasa yang menggunakan lambang-lambang bunyi bahasa dengan penekanan pada penulisan ejaan dan tanda baca. Selain itu, ragam bahasa tulis memegang peranan penting dalam kehidupan sehari-hari terutama bagi peneliti.

Penulis yang baik akan memperhatikan selain dari ejaan dan tanda baca, juga pilihan kata sehingga pembaca mudah memahami tulisannya. Berbagai tulisan ditulis oleh penulis, termasuk menulis karya sastra. Konsep tersebut peneliti dapati dari media internet dan juga dari materi mata Analisis Pemakaian Bentuk-Bentuk Pronomina Persona Dalam Novel Tahajud Cinta Di Kota New York Karya Arumi E. 
kuliah sosiolinguistik mengenai ragam bahasa.

Penulisan karya sastra sangat mempertimbangkan pilihan-pilihan kata yang estetis. Penulisan karya sastra dengan bahasa yang indah menjadikan penikmat karya sastra terhibur akan karya sastra tersebut. Karya sastra diciptakan penulis melalui pemikiran imajinasi. Penulisan karya sastra tidak terlepas dari berbagai aspek kebahasaan, salah satunya ialah pemakaian pronomina. Oleh karea itu, menulis karya sastra juga harus mempertimbangkan penggunaan pilihan kata dalam bahasa. Kata-kata yang digunakan dalam menulis karya sastra apalagi dalam bentuk novel, tidak terlepas dari penggunaan pronomina, khususnya pronomina persona.

Pronomina merupakan bentuk bahasa baik berupa kata maupun bentuk lainnya yang berfungsi sebagai penunjuk hal atau fungsi tertentu di luar bahasa. "Ada tiga macam pronomina dalam bahasa Indonesia, yakni; pronomina persona, pronomina penanya, dan pronomina penunjuk" (Alwi, dkk. 1995: 273). Berdasarkan pernyataan ini peneliti tertarik untuk mengkaji salah satu dari jenis pronomina, yaitu pronomina persona.

Pronomina persona ini sering juga terdapat dalam penulisan novel. Dalam novel populer pronomina persona ini sering terdapat pronomina persona yang tidak baku, seperti gue, elo, lo dan sebagainya. Hal ini menjadi tertarik bagi peneliti untuk menganalisis bagaimana bentuk penggunaan pronomina persona dalam karya sastra yang berbentuk novel. Selama ini peneliti mencermati analisis pronomina persona dilakukan untuk teks-teks kebahasaan saja, kali ini peneliti mencoba untuk menganalisis pronomina persona dalam karya sastra yang berbentuk novel.
Novel merupakan salah satu jenis karya sastra yang digemari oleh masyarakat. Karya sastra jenis novel jalan ceritanya tidak jauh dari realitas kehidupan masyarakat. Novel ini mengemukakan permasalahanpermasalahan yang kompleks tentang kehidupan masyarakat. Novel ini menceritakan tentang perjalanan kehidupan manusia melalui tokoh cerita, biasanya novel melukiskan suka duka, cinta, religius, dan adat istiadat. Melalui novel penikmat dapat menilai sisi baik, buruk, dan juga dapat mengambil hikmah dari jalan cerita yang dikisahkan dalam novel.

\section{STUDI KEPUSTAKAAN}

Bahasa merupakan satu-satunya alat penghubung aktifitas dalam berkomunikasi. "Bahasa adalah alat yang ampuh untuk menghubungkan dunia seseorang dengan dunia di luar diri kita, dunia seseorang dengan lingkungannya, dunia seseorang dengan alamnya, bahkan dunia seseorang dengan Tuhannya" (Pateda, 2011: 6). Melalui bahasa, manusia dapat menyampaikan segala hal kepada siapapun.

Dalam berkomunikasi, manusia pada umumnya menggunakan bahasa sebagai alat komunikasi. "Bahasa adalah sistem lambang bunyi yang arbitrer yang digunakan oleh para anggota kelompok sosial untuk bekerja sama, berkomunikasi, dan mengidentifikasikan diri" dikatakan oleh Kridalaksana (dalam Chaer, 2007). Dengan menggunakan bahasa, manusia lebih mudah dalam berkomunikasi.

Ragam bahasa merupakan suatu hal yang dipentingkan dalam berbahasa atau dalam berkomunikasi. Ragam bahasa memiliki porsi dan ketentuan masing-masing dalam menggunakan bahasa. Menurut (Chaer, 2011: 3-4) 
menyimpulkan bahwa ragam bahasa memiliki tujuh ragam bahasa, di antaranya ialah sebagai berikut:

1. Ragam bahasa yang bersifat perseorangan (idiolek);

2. Ragam bahasa yang digunakan oleh sekelompok anggota masyarakat dari wilayah tertentu (dialek);

3. Ragam bahasa yang digunakan oleh sekelompok anggota masyarakat dari golongan sosial tertentu (sosiolek);

4. Ragam bahasa yang digunakan dalam kegiatan suatu bidang tertentu (fungsiolek);

5. Ragam bahasa yang digunakan dalam situasi formal atau situasi resmi;

6. Ragam bahasa yang digunakan dalam situasi informal atau situasi tidak resmi;

7. Ragam bahasa yang digunakan secara lisan (bahasa lisan) dan ragam bahasa tulisan (bahasa tulis).

Dalam ragam bahasa, khususnya ragam bahasa tulis, tentu kita harus memahami kaedah-kaedah yang terkandung di dalamnya, termasuk dalam ruang lingkup sintaksis yang mempelajari tentang kalimat atau dalam ragam bahasa tulis.

Sintaksis termasuk ilmu yang mempelajari tentang tataran kalimat dalam bahasa Indonesia. "Sintaksis adalah cabang linguistik yang membicarakan hubungan antarkata dalam tuturan (speech)" (Arifin dan Junaiyah, 2008: 1). Apa yang dituturkan berupa kalimat disebut sintaksis. Menurut Ramlan (dalam Tarigan, 1986: 3) mengatakan bahwa "Sintaksis adalah bahagian dari tata bahasa yang membicarakan struktur frasa dan kalimat". Sebuah frasa atau kalimat dengan struktur yang jelas dapat dikatakan sebagai frasa atau kalimat yang kompleks dalam tataran sintaksis.

Pembentukan dalam sebuah kalimat tersebut tidak lepas dari susunan dari beberapa kata, kata dan sebagainya tersebut termasuk dalam kajian morfologi yang membahas tentang konsep kata.

Morfologi disebut juga ilmu bahasa yang mempelajari seluk beluk kata. "Kata Morofologi berasal dari kata morphologie. Kata tersebut berasal dari bahasa Yunani, morphe yang digabungkan dengan logos. Morphe berarti bentuk dan logos berarti ilmu" (dalam buku panduan kuliah Morfologi Bahasa Indonesia).

Menurut (Ramlan, 2009: 21) mengatakan bahwa "Morfologi ialah bagian dari ilmu bahasa yang membicarakan atau yang mempelajari seluk beluk bentuk kata serta pengaruh perubahan-perubahan bentuk kata terhadap golongan dan arti kata". Morfologi ilmu yang mempelajari kata beserta makna kata.

Dalam ilmu kajian morfologi banyak mempelajari tentang kata. Seperti penggunaan, fungsi, makna, dan sebagainya. Selain itu, dalam ilmu morfologi juga mempelajari tentang kelas kata yang dibagi dalam beberapa bagian menurut pakar tertentu.

Kelas kata termasuk dalam tataran morfologi yang menjadi perangkat untuk masing-masing penggunaannya. Kridalaksana berpendapat mengenai kelas kata bahwa, berikut penjelasannya:

Sebagai kesimpulan dari pembahasan tentang kelas kata ini, bisa dikatakan penentuan kata-kata berdasarkan kelas atau golongan memang perlu dilakukan. Namun, kalau sampai kini ternyata banyak menimbulkan persoalan, terutama untuk bahasa Indonesia, kiranya patokan atau kriterianya itu yang perlu dipikirkan kembali, dicari yang betul-betul memang bisa 
mengungkapkan ciri yang paling hakiki dari setiap kelas kata itu. Kridalaksana 1986 dan Ramlan 1985 (dalam Chaer, 2007: 169).

Selain dari Kridalaksana, ada pendapat lain yang mengemukakan teori tentang kelas kata, yang mengemukakan bahwa "Kelas kata adalah perangkat kata yang sedikit banyak berperilaku sintaktis sama. Subkelas kata adalah bagian dari suatu perangkat kata yang berperilaku sintaktis sama". (Kridalaksana, 1986: 41). Klasifikasi atau penggolongan kata itu memang perlu, sebab besar manfaatnya, baik secara teoritis dalam studi semantik, maupun secara praktis dalam berlatih keterampilan berbahasa.

Kelas kata terbagi menjadi beberapa bagian. Para pakar memiliki pendapat masing-masing, namun dari pendapat pakar-pakar tersebut, salah satu dari bagian kelas kata tersebut ialah Pronomina atau kata ganti.

Pronomina merupakan kategori yang berfungsi sebagai kata pengganti. Menurut C.A. Mees (dalam Ramlan, 1991: 11) "Pronomina ialah kata-kata yang menunjuk, menyatakan, atau menanyakan tentang sebuah substansi dan dengan demikian justru mengganti namanya". Pronomina berfungsi untuk mengganti nomina dalam bentuk kata ganti. Dalam buku yang sama, pakar ini mengatakan bahwa "Kata ganti atau pronomina ialah kata-kata yang menunjuk, menyatakan atau menanyakan tentang sebuah substansi dan dengan demikian justru mengganti namanya" (Ramlan, 1991: 11). Dengan konsep pronomina ini menjadikan peneliti mudah dalam melakukan penelitian yang terkait tentang pronomina tersebut.

Pronomina memiliki berbagai jenis. Menurut (Alwi, dkk., 1995: 273)
"Ada tiga jenis pronomina dalam bahasa Indonesia, yakni (1) pronomina persona, (2) pronomina penunjuk, (3) pronomina penanya. Ketiga jenis pronomina tersebut, salah satunya menjadi objek penelitian peniliti dalam penelitian ini.

Menurut (Alwi, dkk., 1995: 274-

280) Pronomina persona adalah "Pronomina yang dipakai untuk mengacu ke orang. Pronomina persona dapat mengacu pada diri sendiri (pronomina persona pertama, mengacu pada orang yang diajak bicara (pronomina persona kedua), atau mengacu pada orang yang dibicarakan (pronomina persona ketiga)". Menurut C.A. Mees (dalam Ramlan, 1990: 11) mengatakan bahwa "Pronomina persona atau kata ganti persona ialah kata-kata yang mengganti nama persona. Dapat digolongkan menjadi kata ganti persona pertama, kata ganti persona kedua, dan kata ganti persona ketiga". Hanya pada kata ganti orang yag dapat digolongkan dalam pronomina persona.

Adapun di dalam kata ganti orang (persona) kemudian terbagi lagi menjadi tiga bentuk, yakni pronomina persona pertama, pronomina persona kedua, dan pronomina persona ketiga. Persona pertama digunakan untuk mengganti diri sendiri. "Persona pertama tunggal bahasa Indonesia adalah saya, aku, dan daku. Ketiga bentuk ini adalah bentuk baku, tetapi mempunyai tempat pemakaian yang agak berbeda. Saya adalah bentuk yang formal dan umumnya dipakai dalam tulisan atau ujaran yang resmi. Namun, sebagian orang memakai pula bentuk kami dengan arti saya untuk situasi formal”. (Alwi, dkk., 1995: 276). Hal ini dimaksudkan untuk tidak terlalu menonjolkan diri. Persona kedua dipakai untuk mengganti nama orang yang diajak bicara. "Persona kedua tunggal mempunyai beberapa wujud, 
yakni engkau, kamu, anda, dikau, kaudan -mu. Persona kedua mempunyai bentuk jamak. Ada dua macam bentuk jamak: (1) kalian, dan (2) persona kedua ditambah dengan kata sekalian: Anda sekalian, dan kamu sekalian. Meskipun kalian tidak terikat pada tata krama sosial, orang muda atau yang status sosialnya lebih rendah umumnya tidak memakai bentuk itu terhadap orang tua atau atasannya. Persona ketiga digunakan untuk mengganti nama orang yang dibicarakan. "Ada dua macam persona ketiga tunggal: (1) ia, dia, atau -nya dan (2) beliau. Meskipun ia dan dia dalam banyak hal berfungsi sama, ada kendala tertentu yang dimiliki oleh masing-masing. Dalam posisi sebagai subjek, atau di depan verba, ia dan dia sama-sama dapat dipakai. Akan tetapi, jika berfungsi sebagai objek, atau terletak di sebelah kanan dari yang diterangkan, hanya bentuk dia dan -nya yang dapat muncul" (Alwi, dkk., 1995: 280). Selain dari persona ketiga tunggal, adapula persona ketiga jamak, yang dimaksudkan lebih banyak.

Pronomina persona banyak ditemukan dalam bentuk tulisan. Termasuk dalam sebuah karya sastra. Karya sastra yang menurut peneliti banyak menggunakan pronomina persona di dalamnya ialah Novel.

Dalam artian luas, novel adalah cerita berbentuk prosa dalam ukuran yang luas. Ukuran yang luas maksudnya cerita dengan plot (alur) yang kompleks, karakter yang banyak, tema yang kompleks, suasana cerita yang beragam, dan setting cerita yang beragam pula.

Novel merupakan karya sastra dari penulis yang mengungkapkan hasil pikiran imajinatifnya ke dalam tulisan. "Novel adalah karya imajinatif yang mengisahkan sisi utuh problematika kehidupan seseorang atau beberapa orang tokoh" (Kosasih, 2012: 60).
Selanjutnya "Novel adalah suatu cerita yang bermain dalam dunia manusia dan benda yang ada di sekitar kita, tidak mendalam, lebih banyak melukiskan satu saat dari kehidupan seseorang, dan lebih mengenai sesuatu episode" Jassin (dalam Nurgiyantoro, 2010: 18). Tak jarang novel yang memiliki cerita lanjutan dalam beberapa episodenya.

Langkah kerja dalam meneliti sebuah penelitian, khususnya meneliti kajiaan kebahasaan di dalam sebuah novel, tentu harus memiliki landasan yang kuat. Dalam penelitian ini, peneliti menggunakan pendekatan struktural, guna memperjelas langkah peneliti dalam melakukan penelitian ini.

Pendekatan merupakan cara dalam memulai melakukan sesuatu. Pendekatan struktural merupakan cara dalam mengidentifikasi suatu masalah dalam penelitian dengan terstruktur. Menurut Chaer mengungkapkan bahwa:

Pandangan yang dimuat oleh Ferdinand de Saussure dalam bukunya yang berjudul Course de Linguistique Generale mengenai konsep; (1) telaah sinkronik dan diakronik, (2) perbedaan langue dan parole, (3) perbedaan signifiant dan signifié, dan (4) hubungan sintamagtik dan paradigmatik baanyak berpengaruh dalam perkembangan linguistik di kemudian hari (Chaer, 2007: 346).

Berdasarkan apa yang diungkapkan oleh Chaer tersebut, peneliti mengambil konsep keempat sebagai konsep penelitian dalam penelitian yang peneliti lakukan ini. Konsep tersebut ialah:

Hubungan Sintamagtik dan Paradigmatik. Ferdinan de Saussure membedakan adanya dua macam hubungan, yaitu hubungan sintamagtik dan 
hubungan paradigmatik. Yang dimaksud dengan hubungan sintamagtik adalah hubungan antara unsur-unsur yang terdapat dalam satu tuturan, yang tersusun secara verurutan, bersifat linear. Hubungan sintamagtik ini terdapat, baik dalam tataran fonologi, morfologi, maupun sintaksis.

Hubungan sintamagtik pada tataran morfologi tampak pada urutan morfem-morfem pada suatu kata, yang juga tidak dapat diubah tanpa merusak makna dari kata tersebut. Ada kemungkinan maknanya berubah, tetapi ada kemungkinan pula tak bermakna sama sekali. Hubunga sintamagtik pada tataran sintaksis tampak pada urutan kata-kata yang mungkin dapat diubah, tetapi mungkin juga tidak dapat diubah tanpa mengubah makna kalimat tersebut, atau menyebabkan tak bermakna sama sekali.

Hubungan paradigmatik adalah hubungan antara unsur-unsur yang terdapat dalam suatu tuturan dengan unsur-unsur sejenis yang tidak terdapat dalam tuturan yang bersangkutan. Hubungan paradigmatik dapat dilihat dengan cara substitusi, baik pada tataran fonologi, morfologi, maupun tataran sintaksis (Chaer, 2007: 349).

Strukturalis dalam bahasa berusaha mendeskripsikan suatu bahasa berdasarkan ciri atau sifat khas dan bentuk yang dimiliki bahasa itu. Dalam penelitian ini sejalan dengan apa yang diungkapkan oleh Sudaryanto dalam bukunya Metode dan Aneka Teknik Analisis Bahasa. \begin{tabular}{lrr}
\multicolumn{2}{c}{ Pendekatan } & struktural \\
merupakan & kajian & yang \\
mendeskripsikan & suatu & bahasa
\end{tabular} berdasarkan ciri atau sifat khas yang dimiiki bahasa itu sendiri. Telah banyak para ahli yang memiliki pandangan tentang strukturalis bahasa, selain dari Ferdinand de Saussure, Sudaryanto juga sependapat mengenai strukturalis bahasa tentang peristilahan: "penyediaan" dan "analisis".

\section{METODE PENELITIAN}

Jenis penelitian merupakan bagian dari metode penelitian. Jenis penelitian yang peneliti gunakan dalam penelitian ini ialah penelitian kualitatif yang berkaitan dengan kajian bahasa dalam objek karya sastra. Penelitian ini menggunakan pendekatan deskriptif kualitatif.

Jenis penelitian dalam penelitian ini menggunakan metode deskriptif kualitatif. "Metode penelitian pada dasarnya merupakan cara ilmiah untuk mendapatkan data dengan tujuan dan kegunaa tertentu. Berdasarkan hal tersebut terdapat empat kunci yang perlu diperhatikan yaitu cara ilmiah, data, tujuan, dan kegunaan" (Sugiyono, 2013: 2). Metode penelitian merupakan cara dalam sebuah penelitian untuk mencapai tujuan penelitian yang optimal.

Jenis penelitian deskriptif merupakan cara yang digunakan dalam penelitian untuk memecahkan masalah dengan mendeskripsikan data-data berdasarkan fakta yang ada. "Deskriptif adalah sifat data penelitian kualitatif. Wujud datanya berupa deskripsi objek penelitian. Dengan kata lain, wujud data penelitia kualitatif adalah kata-kata, gambar, dan angka-angka yan tidak dihasilkan melalui pengolahan statistika" (Muhammad, 2011: 34). Dengan metode deskriptif, peneliti 
dituntut mengungkapkan fakta-fakta dari objek dengan cara deskriptif. Penelitian deskriptif merupakan sifat dari penelitian kualitatif.

Penelitian bahasa dengan objek karya sastra yang peneliti kemukakan ini merupakan penelitian yang digunakan untuk meneliti kondisi objek yang bersifat alamiah, untuk mendapatkan data yang mendapatkan data yang diinginkan. Melalui penelitian kualitatif, peneliti dapat melakukan eksplorasi terhadap suatu objek yang diteliti. Metode kualitatif ini dapat membantu peneliti dalam memahami objek yang akan diteliti, baik berupa tuturan maupun kata-kata yang mengandung pronomina persona.

Tempat penelitian yang akan peneliti gunakan dalam penelitian ini ialah bertempat di Jambi. Waktu penelitian yang akan peneliti gunakan dalam penelitian ini dimulai dari tanggal 16 November 2016 hingga 16 Mei 2017, sesuai dikeluarkan SK bimbingan Nomor 315 Tahun 2016.

Data primer yang terdapat dalam penelitian ini berupa kutipan-kutipan yang mengandung pronomina persona yang terdapat dalam novel Tahajud Cinta di Kota New York karya Arumi E. Novel ini peneliti beli secara online sejak dua tahun yang lalu.

. Data sekunder merupakan data pendukung yang diperoleh dari berbagai sumber, seperti buku-buku tentang bahasa atau linguistik, buku tentang sintaksis, buku tentang morfologi, buku tentang kelas kata, buku penelitian bahasa dan sastra, buku tentang sastra, media internet, dan novel yang menjadi objek kajian peneliti.

Sumber data primer penelitian ini bersumber dari teks-teks novel, (narasi dan dialog). Sumber data diperoleh dari novel Tahajud Cinta di Kota New York karya Arumi E. Novel ini merupakan buah karya Arumi E. yang kedelapan, diterbitkan oleh Zettu di Jakarta Timur, merupakan cetakan pertama pada Maret 2013, berjumlah 420 halaman. Novel ini dicetak dengan kertas ringan berwarna krem, dengan harga Rp. 65. 000,-. Sampul depan dari novel ini berlatar belakang kota New York. Di atas tertulis judul dari novel tersebut dan di bawah judul novel tertera nama penulisnya, yakni Arumi E.

Sumber data sekunder pada penelitian ini selain yang dijelaskan di atas juga ada sumber data yang lain sebagai pendukung atau untuk memperkuat penelitian ini, di antaranya Perpustakaan FKIP Universitas Batanghari, Perpustakaan Wilayah Jambi, hasil pinjaman dari teman dan beberapa dosen prodi pendidikan bahasa dan sastra Indonesia, media internet, dan buku-buku yang berkaitan dengan linguistik dan sastra.

Teknik pengumpulan data dalam penelitian ini dilakukan dengan cara sebagai berikut:

1. Penulis membaca dengan teliti dan berulang-ulang, serta memahami isi novel Tahajud Cinta di Kota New York karya Arumi E.

2. Penulis menandai dengan menggunakan penanda atau stabilo pada bagian kata-kata atau ujaran yang termasuk dalam pronomina persona.

3. Penulis mengklasifikasikan bagianbagian tentang pronomina persona yang telah ditandai sebelumya berdasarkan landasan atau teori yang digunakan, yakni pronomina persona pertama, pronomina persona kedua, dan pronomina persona ketiga.

Dalam teknik analisis data ini menggunakan teknik analisis dan deskripsi. Kemudian peneliti memasukan data tersebut ke dalam tabel tabulasi data dengan tujuan untuk 
mempermudah bagi peneliti untuk mencapai tujuan penelitian ini tentang pemakaian bentuk pronomina persona dalam novel Tahajud Cinta di Kota New York karya Arumi E.

\section{HASIL PENELITIAN DAN PEMBAHASAN}

Pada penelitian ini peneliti menemukan sebanyak 559 data. Berdasarkan data yang diperolah, peneliti menemukan beberapa bentuk pronomina persona. Pronomina persona yang peneliti temukan dalam penelitian ini berupa pronomina persona pertama, pronomina persona kedua, dan pronomina persona ketiga. Ketiga bentuk pronomina persona tersebut terbagi pula menjadi beberapa bentuk khusus di dalamnya. Bentuk dari pronomina persona tersebut peneliti temukan pada kutipan-kutipan dalam novel Tahajud Cinta di Kota New York karya Arumi E. Penggunaan pronomina persona pada novel ini tidak hanya digunakan hanya dengan satu tokoh saja. Satu bentuk pronomina persona pada penggunaannya dalam novel ini digunakan lebih dari satu tokoh.

\section{Pemakaian Bentuk-bentuk Pronomina Persona Pertama}

Pada pemakaian bentuk-bentuk pronomina persona pertama dalam novel ini menempati urutan kedua pemakaiannya dengan jumlah data yang peneliti dapatkan sebanyak 171 data. Data yang peneliti dapatkan dibagi menjadi beberapa bentuk, yakni data pronomina persona pertama tunggal terdapat lima variasi bentuk, di antaranya terdapat 80 bentuk 'Aku', 44 bentuk '-ku', satu bentuk 'Ku-', lima bentuk 'Saya', dan 19 bentuk 'Gue' yang termasuk bentuk pronomina persona pertama tunggal tak baku. Selain itu, peneliti juga menemukan data pronomina persona pertama jamak. Data pronomina persona pertama jamak yang peneliti dapatkan dalam novel ini terdapat empat bentuk 'Kami', dan 18 bentuk 'Kita'.

\section{Pemakaian Bentuk-bentuk Pronomina Persona Kedua}

Pada pemakaian bentuk-bentuk pronomina persona kedua dalam novel ini menempati urutan terakhir dengan pemakaian paling sedikit, yakni terdapat 147 data. Data bentuk pronomina persona kedua daam novel ini dibagi menjadi bentuk pronomina persona kedua tunggal dan bentuk pronomina persona kedua jamak. Data pronomina persona kedua tunggal yang peneliti dapatkan pada novel ini dibagi menjadi enam variasi bentuk, yakni 33 bentuk 'Kamu', 43 bentuk 'mu', 24 bentuk 'Kau', 34 bentuk 'Elo', tujuh bentuk 'Lo', lima bentuk 'Anda'. Bentuk pronomina persona kedua tunggal 'Elo' dan 'Lo' merupakan bentuk pronomina persona kedua tunggal yang tak baku. Selain itu, peneliti juga menemukan bentuk pronomina persona kedua jamak dengan satu data, yakni satu bentuk 'Kalian'.

\section{Pemakaian Bentuk-bentuk Pronomina Persona Ketiga}

Pada pemakaian bentuk-bentuk pronomina persona ketiga dalam novel ini menempati urutan pertama dengan pemakaian terbanyak sebanyak 241 data. Data yang peneliti dapatkan dalam novel ini peneliti bagi menjadi dua bagian, yakni data pronomina persona ketiga tunggal dan data pronomina persona ketiga jamak. Pada data pronomina persona ketiga tunggal terdapat 95 bentuk 'ia', 11 bentuk 'dia', dan 120 bentuk '-nya'. Selain itu, peneliti juga menemukan bentuk pronomina persona ketiga jamak dengan jumalah satu data saja, yakni 15 bentuk 'mereka'. 
Pembahasan dalam penelitian ini, membahas tentang pemakaian bentuk-bentuk pronomina persona dalam novel Tahajud Cinta di Kota New York karya Arumi E. Dalam novel tersebut bentuk-bentuk pronomina persona terdapat pada tataran kata maupun dalam ujaran. Bentuk-bentuk pronomina tersebut terbagi menjadi tiga bagian, yakni pronomina persona pertama, pronomina persona kedua, dan pronomina persona ketiga.

\section{KESIMPULAN}

Berdasarkan hasil penelitian dan pembahasan yang terdapat pada BAB IV mengenai bentuk-bentuk pronomina persona dalam novel Tahajud Cinta di Kota New York karya Arumi E. maka dapat disimpulkan dari beberapa data yang telah peneliti peroleh ialah sebagai berikut. Pada novel Tahajud Cinta di Kota New York karya Arumi E. terdapat 559 data. Di antaranya terdapat 171 data tentang pronomina persona pertama yang dibagi menjadi tujuh variasi bentuk, yakni 80 data 'Aku', 44 data '$\mathrm{ku}$ ', satu data 'Ku-', lima data 'Saya', 19 data 'Gue', empat data 'Kami', dan 18 data 'Kita'. Selanjutnya pada data tentang pronomina persona kedua terdapat 147 data yang dibagi menjadi tujuh variasi bentuk, yakni 33 data 'Kamu', 43 data '-mu', 24 data 'Kau', 34 data 'Elo, tujuh data 'Lo', lima data 'Anda', dan satu data 'Kalian'. Terakhir untuk data pronomina persona ketiga terdapat 241 data yang dibagi menjadi empat variasi bentuk, yakni 95 data 'ia', 11 data 'Dia', 120 data '-nya', dan 15 data 'Mereka'.

Dari uraian di atas dapat disimpulkan bahwa dalam novel Tahajud Cinta di Kota New York karya Arumi E. terdapat tiga bentuk pronomina persona dengan 17 variasi bentuk yang digunakan oleh penulis.
Bentuk-bentuk pronomina persona yang digunakan oleh penulis dalam novel ini berupa pronomina persona pertama, pronomina persona kedua, dan pronomina persona ketiga.

\section{SARAN}

Berdasarkan dari uraian sebelumnya, terkait penelitian ini hanya terbatas pada pemakaian bentuk-bentuk pronomina persona dalam novel Tahajud Cinta di Kota New York karya Arumi E. Maka diharapkan penelitian ini dapat berlanjut untuk diteliti, mengingat data dalam ini merupakan data murni yang tidak diubah penulisannya, baik ejaan maupun pola kalimatnya. Dengan demikian, untuk penelitian selanjutnya data dalam penelitian ini dapat dijadikan sumber data yang mungkin dapat diteliti dari segi aspek lainnya.

\section{DAFTAR PUSTAKA}

Alwi, Hasan, dkk. 1995. Tata Bahasa Baku Bahasa Indonesia. Jakarta: Balai Pustaka

Arifin, Zaenal dan Junaiyah. 2008. Sintaksis. Jakarta: PT. Grasindo

Chaer, Abdul. 2007. Linguistik Umum. Jakarta: Rineka Cipta . 2011. Tata Bahasa Praktis

Bahasa Indonesia. Jakarta: Rineka Cipta

\section{Analisis Pemakaian Bentuk-Bentuk Pronomina Persona Dalam Novel Tahajud Cinta Di Kota New York} Karya Arumi E. 
Kosasih, E. 2012. Dasar-dasar Keterampilan

Bersastra.

Bandung: Yrama Widya

Kridalaksana, Harimurti. 1986. Kelas

Kata dalam Bahasa Indonesia. Jakarta: PT. Gramedia

Muhammad. 2011. Metode Penelitian

Bahasa. Yogyakarta: Ar-Ruzz

Media

Pateda, Mansoer. 2011. Linguistik (Sebuah Pengantar). Bandung:
Ramlan, M. 2009. Morfologi Suatu Tinjauan Deskriptif. Yogyakarta: C.V. Karyono . 1991. Tata Bahasa Indonesia Penggolongan Kata.

Yogyakarta: Andi Offset

Sugiyono. 2013. Metode Penelitian Kuantitatif Kualitatif dan $R \& D$. Bandung: Alfabeta

Tarigan, Henry Guntur. 1986. Prinsipprinsip Dasar Sintaksis. Bandung: Angkasa

Angkasa 